\section{Cureus}

Received 01/30/2018

Review began 02/02/2018

Review ended 02/02/2018

Published 02/04/2018

\section{C) Copyright 2018}

Chowdhury et al. This is an open access article distributed under the terms of the Creative Commons Attribution License CC-BY 3.0., which permits unrestricted use, distribution, and reproduction in any medium, provided the original author and source are credited.

\title{
Metformin-Induced Lactic Acidosis: A Case Study
}

\author{
Waliul Chowdhury ${ }^{1}$, Muhammad Uzair Lodhi ${ }^{1}$, Intekhab Askari Syed ${ }^{1}$, Umer Ahmed ${ }^{2}$, \\ Maxwell Miller ${ }^{3}$, Mustafa Rahim ${ }^{4}$ \\ 1. Medical Student, Department of Medicine, Raleigh General Hospital, Beckley, Wv 2. Research \\ Associate, Broad Institute of Mit and Harvard 3. Medical Student, Department of Medicine, Lincoln \\ Memorial University-Debusk College of Osteopathic Medicine 4. Assistant Clinical Professor of Internal \\ Medicine, West Virginia University School of Medicine
}

$\square$ Corresponding author: Umer Ahmed, uahmed25@gmail.com

Disclosures can be found in Additional Information at the end of the article

\section{Abstract}

Metformin is the first line management for patients with Type 2 diabetes mellitus. Metformininduced lactic acidosis (MALA) is a severe side effect of metformin in high doses.

However, there have not been many reported cases of MALA. The threshold metformin concentration needed to induce lactic acidosis is still not fully understood. It is important for physicians to measure metformin levels upon admission in Type 2 diabetes patients who take metformin and present with suspected lactic acidosis. We present a case of a 40-year-old Caucasian male who presented with severe lactic acidosis shortly after overdosing on metformin.

Categories: Endocrinology/Diabetes/Metabolism, Family/General Practice, Internal Medicine Keywords: metformin, lactic acidosis, metformin overdose

\section{Introduction}

Metformin works as an antihyperglycemic agent and promotes euglycemia. However, metformin can exacerbate hypoglycemia in patients who take other glucose-lowering drugs, such as sulfonylureas [1-2]. The major side effect of metformin is lactic acidosis [1-5]. There are few cases reported on Type 2 diabetes patients presenting with lactic acidosis where metformin was the major inducing factor. We will present a 40-year-old male patient who overdosed on metformin and developed lactic acidosis the following day.

\section{Case Presentation}

A 40-year-old Caucasian male smoker presented with malaise. He mentioned feeling like this for the past three months but not as severe as when he was admitted. He did not mention any chest pain, heaviness, or pressure. He denied fever, chills, diarrhea, constipation, abdominal pain, nausea, or vomiting. He also denied odynophagia, dysphagia, hematemesis, hematochezia, hematuria, or dysuria. He did not mention having any rashes, discoloration, or depigmentation of the skin. He denied any alcohol or substance abuse. His past medical history included: Type 2 diabetes mellitus, bipolar disorder, chronic obstructive pulmonary disease, gastroesophageal reflux disease, and arthritis. His past surgeries included a cholecystectomy and a right-sided ankle fusion. His home medications included metformin (1,000 mg twice a day), acetaminophen (as needed), amlodipine ( $5 \mathrm{mg}$ once daily), famotidine (20 $\mathrm{mg}$ twice a day), gabapentin (100 mg three times a day), glipizide (5 mg once a day), lurasidone ( $80 \mathrm{mg}$ once a day), and mirtazapine (15 mg once a day). 


\section{Cureus}

Upon physical examination, he was not in acute distress. His vitals were as follows: afebrile, blood pressure of 178/107, heart rate of 115 , respiratory rate of 20 breaths per minute, and an oxygen saturation of $96 \%$. His pupils were equal, round, and reactive to light and accommodation. There was no pallor or icterus. Extraocular movements were normal. There was no nystagmus or strabismus. The neck was supple with no thyromegaly, lymphadenopathy, or carotid bruits. Cardiac auscultation revealed a regular rhythm without murmurs or gallops and audible S1 and S2. Respiratory sounds were clear to auscultation with no crackles, wheezes, or bronchial breath sounds. The abdomen was soft and non-tender with no visceromegaly or abnormal masses. His bowel sounds were clearly audible. His extremities showed no peripheral edema, clubbing, or cyanosis. His peripheral pulses were symmetrical and normal.

His cardiac markers were all negative. On admission, his lactate level was 7.1 (Table 1). His metformin level was $14 \mathrm{mcg} / \mathrm{mL}$ on Day 2 of admission. The remainder of his labs, including a complete metabolic panel (Table 2), complete blood count (Table 3), and toxicology report (Table 4), is shown below.

\begin{tabular}{|c|c|c|c|}
\hline Plasma level (mmol/L) & Day of admission & Time & Reference Range (mmol/L) \\
\hline 7.1 & Day 2 & $06: 50$ & $0.4-2.0$ \\
\hline 4.5 & Day 2 & 13:12 & $0.4-2.0$ \\
\hline 0.4 & Day 4 & 04:30 & $0.4-2.0$ \\
\hline
\end{tabular}

\section{TABLE 1: Blood Lactate Concentration}




\section{Cureus}

\begin{tabular}{|c|c|c|c|c|}
\hline & Time & Value & Units & $\begin{array}{l}\text { Reference } \\
\text { Range }\end{array}$ \\
\hline Glucose (Glu) & Day 1 & 188 & $\mathrm{mg} / \mathrm{dL}$ & $70-99$ \\
\hline Ammonia & Day 1 & 60 & Umol/L & $11-32$ \\
\hline Chloride (Cl) & Day 1 & 111 & $\mathrm{mEq} / \mathrm{L}$ & $98-107$ \\
\hline Calcium (Ca) & Day 1 & 8.3 & $\mathrm{mg} / \mathrm{dL}$ & $8.5-10.2$ \\
\hline Albumin & Day 1 & 3.3 & $\mathrm{~g} / \mathrm{dL}$ & $3.5-5.5$ \\
\hline $\begin{array}{l}\text { Aspartate aminotransferase serum glutamic oxaloacetic } \\
\text { transaminase (AST SGOT) }\end{array}$ & Day 1 & 54 & $\mathrm{U} / \mathrm{L}$ & $10-40$ \\
\hline $\begin{array}{l}\text { Alanine aminotransferase serum glutamic oxaloacetic } \\
\text { transaminase (ALT SGOT) }\end{array}$ & Day 1 & 37 & $\mathrm{U} / \mathrm{L}$ & $7-56$ \\
\hline Total Bilirubin & $\begin{array}{l}\text { Day } 1, \\
\text { Day } 3\end{array}$ & $\begin{array}{l}1.6 \\
1.0\end{array}$ & $\mathrm{mg} / \mathrm{dL}$ & $0.2-1.0$ \\
\hline Magnesium (Mg) & Day 3 & 2.2 & $\mathrm{mg} / \mathrm{dL}$ & $1.6-2.6$ \\
\hline Phosphate (Phos) & Day 3 & 4.6 & $\mathrm{mg} / \mathrm{dL}$ & $2.5-4.7$ \\
\hline Glomerular filtration rate (GFR) & $\begin{array}{l}\text { Day1, } \\
\text { Day } 3\end{array}$ & $\begin{array}{l}>60 \\
26\end{array}$ & $\begin{array}{l}\mathrm{mL} / \mathrm{min} / 1.73 \\
\mathrm{~m}^{2}\end{array}$ & $90-120$ \\
\hline Blood urea nitrogen/creatinine ratio (BUN/Cr) & $\begin{array}{l}\text { Day } 1, \\
\text { Day } 3\end{array}$ & 13,9 & $\mathrm{mmol} / \mathrm{L}$ & $2.5-7.1$ \\
\hline
\end{tabular}

TABLE 2: Metabolic Panel 


\section{Cureus}

\begin{tabular}{|c|c|c|c|c|}
\hline & Time & Value & Units & Reference Range \\
\hline White blood cells (WBC) & Day 1 & $3.7 \times 10^{3}$ & $\mu \mathrm{L}$ & $4.8-10.8 \times 10^{3}$ \\
\hline Red blood cells (RBC) & Day 1 & $4.11 \times 10^{6}$ & cells $/ \mathrm{mm}^{3}$ & $4.70-6.10 \times 10^{6}$ \\
\hline Hemoglobin (HgB) & Day 1 & 12.5 & $\mathrm{~g} / \mathrm{dL}$ & $14.0-18.0$ \\
\hline Hematocrit (Hct) & Day 1 & 36.9 & $\%$ & $42.0-52.0$ \\
\hline Mean corpuscular volume (MCV) & Day 1 & 89.9 & $\mathrm{fl}$ & $80.0-94.0$ \\
\hline Mean corpuscular hemoglobin (MCH) & Day 1 & 30.5 & pg & $27.0-31.0$ \\
\hline Mean corpuscular hemoglobin concentration (MCHC) & Day 1 & 33.9 & $\mathrm{~g} / \mathrm{dL}$ & $33.0-37.0$ \\
\hline Red cell distribution width (RDW) & Day 1 & 16.2 & $\%$ & $11.5-14.5$ \\
\hline Mean platelet volume (MPV) & Day 1 & 9.8 & $\mathrm{fl}$ & $6.2-10.6$ \\
\hline Platelet count & Day 1 & $68 \times 10^{3}$ & $\mu \mathrm{L}$ & $130-400 \times 10^{3}$ \\
\hline Neutrophil & Day 1 & 63 & $\%$ & $42.0-75.0$ \\
\hline Lymphocyte & Day 1 & 21.8 & $\%$ & $20.0-40.0$ \\
\hline Monocyte & Day 1 & 9.8 & $\%$ & $2.0-7.0$ \\
\hline Basophil & Day 1 & 0.6 & $\%$ & $0.0-1.0$ \\
\hline Eosinophil & Day 1 & 4.8 & $\%$ & $0.0-3.0$ \\
\hline Neutrophil count & Day 1 & $2.4 \times 10^{3}$ & $\mu \mathrm{L}$ & $1.5-7.1 \times 10^{3}$ \\
\hline
\end{tabular}

TABLE 3: Complete Blood Count

\begin{tabular}{|l|l|l|}
\hline Drug & Result & Reference Range \\
\hline Salicylates & $<1.7 \mathrm{mg} / \mathrm{dL}$ & $15-30 \mathrm{mg} / \mathrm{dL}$ \\
Acetaminophen & $3 \mathrm{mg} / \mathrm{mL}$ & $10-30 \mathrm{mg} / \mathrm{mL}$ \\
Alcohol & $<11 \mathrm{mg} / \mathrm{dL}$ & $0-10 \mathrm{mg} / \mathrm{dL}$ \\
\hline
\end{tabular}

TABLE 4: Toxicology Report

\section{Discussion}

Unfortunately, his metformin levels were not measured on the first day of admission. They were measured on Day 2. Measuring his metformin level immediately when his lactic acid level was 7.1 upon admission would have given us an idea what level of metformin was associated with that level of lactic acidosis. All physicians should measure metformin levels immediately 
in Type 2 diabetes patients who present with signs of lactic acidosis upon admission. This would provide enough data to understand the likely threshold level of metformin required to induce lactic acidosis in patients.

It is still being investigated whether measuring metformin and lactate levels have an effect on mortality. For example, Vecchio et al. retrospectively observed 60 patients with cases of lactic acidosis ( $\mathrm{pH}<7.35$, arterial lactate $>5 \mathrm{mmol}$ ) associated with metformin toxicity (plasma level > $4 \mathrm{mcg} / \mathrm{mL}$ ) from 2007 to 2011 . All patients had an acute renal failure in addition to lactic acidosis. They showed metformin concentrations to have a significant correlation with plasma lactate levels $(\mathrm{p}=0.001, \mathrm{R}=0.41)$. However, the mean concentration of metformin and lactate levels were not statistically significant between surviving and deceased patients [4].

Another study by Lalau et al. collected data from 49 metformin-treated patients with lactic acidosis (arterial lactate $>5 \mathrm{mmol} / \mathrm{L}$, blood $\mathrm{pH}<7.35$ ) and analyzed their metformin concentrations. They also showed no significant difference in lactate levels between surviving and deceased patients. However, the mean metformin concentrations were three times higher in the patients who survived $(20.6 \mathrm{mg} / \mathrm{L})$ compared to those who died $(6.3 \mathrm{mg} / \mathrm{L})[5]$. Both studies concluded that neither arterial lactate levels nor plasma metformin concentrations can determine the likelihood of mortality [4-5]. Instead, the extent of underlying comorbid conditions had more of a significant prognostic value [4-5].

The patient also admitted to taking excess amounts of acetaminophen. This contradicts the initial lab analysis, which showed his acetaminophen levels at $3 \mathrm{mg} / \mathrm{mL}$. Subsequent analysis showed his serum acetaminophen to be $54 \mathrm{mg} / \mathrm{mL}$ (reference range $=10-30 \mathrm{mg} / \mathrm{mL}$ ). The initial discrepancy was most likely a lab error.

Acetaminophen is well known for causing liver injury when taken in toxic amounts [6]. Acetaminophen-induced hepatotoxicity occurs through the formation of the metabolite Nacetyl-para-benzo-quinone imine (NAPQI), which depletes glutathione stores. This causes oxidative stress and damage to the liver's mitochondria, which inhibits the body's ability to produce adenosine triphosphate (ATP). NAPQI also binds to cellular proteins, such as mitochondrial proteins. This decreases important antioxidant functions and disrupts the mitochondrial ATP synthase alpha subunit, which all deplete ATP formation. The end result is the formation of centrilobular necrosis of the liver [6].

Acetaminophen-induced liver damage could play a role in exacerbating the effects of MALA. This is because of lactate produced by muscle cells via anaerobic glycolysis shifts to the liver. The liver acts by converting the lactic acid into glucose via gluconeogenesis [7]. If there is liver damage, gluconeogenesis could be affected causing a build-up of a lactic acid substrate in the body.

Intravenous (IV) hydration was successfully used to control the lactic acidosis. However, other treatments are available. For example, a recent study by Oyaizu-Toramaru et al. investigated the use of targeting oxygen-sensing prolyl hydroxylase (PHD) in patients with metformininduced lactic acidosis. They found that inhibiting PHD activates a transcription factor, known as hypoxia-inducible factor (HIF), which promotes lactate efflux and gluconeogenesis by using lactate as the substrate; these all lower circulating lactate levels [8]. Even though there are many more treatment options for lactic acidosis, IV hydration therapy was effective in this case.

\section{Conclusions}

Lactic acidosis is a well-known side effect of metformin. However, monitoring lactate and 
metformin levels have not yet been proven to improve the patient's prognosis. Physicians should make it part of their protocol to measure metformin levels in Type 2 diabetics who present with signs and symptoms of possible lactic acidosis. When presented with a case of MALA, IV hydration therapy should be sufficient therapy if diagnosed promptly. Although MALA is rare, it is still possible, as seen in this patient's case, and physicians should be prepared for prompt diagnosis and treatment.

\section{Additional Information}

\section{Disclosures}

Human subjects: Consent was obtained by all participants in this study. Conflicts of interest: In compliance with the ICMJE uniform disclosure form, all authors declare the following:

Payment/services info: All authors have declared that no financial support was received from any organization for the submitted work. Financial relationships: All authors have declared that they have no financial relationships at present or within the previous three years with any organizations that might have an interest in the submitted work. Other relationships: All authors have declared that there are no other relationships or activities that could appear to have influenced the submitted work.

\section{References}

1. Harrigan RA, Nathan MS, Beattie P: Oral agents for the treatment of type 2 diabetes mellitus: pharmacology, toxicity, and treatment. Ann Emerg Med. 2001, 38:68-78. 10.1067/mem.2001.114314

2. Dunn CJ, Peters DH: Metformin. A review of its pharmacological properties and therapeutic use in non-insulin-dependent diabetes mellitus. Drugs. 1995, 49:721-49. 10.2165/00003495199549050-00007

3. Duong JK, Furlong TJ, Roberts DM, et al.: The role of metformin in metformin-associated lactic acidosis (MALA): Case series and formulation of a model of pathogenesis. Drug Saf. 2013, 36:733-46. 10.1007/s40264-013-0038-6

4. Vecchio S, Giampreti A, Petrolini VM, et al.: Metformin accumulation: lactic acidosis and high plasmatic metformin levels in a retrospective case series of 66 patients on chronic therapy. Clin Toxicol (Phila). 2014, 52:129-35. 10.3109/15563650.2013.860985

5. Lalau JD, Race JM: Lactic acidosis in metformin-treated patients. Prognostic value of arterial lactate levels and plasma metformin concentrations. Drug Saf. 1999, 20:377-84. 10.2165/00002018-199920040-00006

6. Yoon E, Babar A, Choudhary M, et al.: Acetaminophen-induced hepatotoxicity: a comprehensive update. J Clin Transl Hepatol. 2016, 4:131-42. 10.14218/JCTH.2015.00052

7. Gerich JE, Meyer C, Woerle HJ, Stumvoll M: Renal gluconeogenesis: its importance in human glucose homeostasis. Diabetes Care. 2001, 24:382-91. 10.2337/diacare.24.2.382

8. Oyaizu-Toramaru T, Suhara T, Hayakawa N, et al.: Targeting oxygen-sensing prolyl hydroxylase for metformin-associated lactic acidosis treatment. Mol Cell Biol. 2017, 37: pii: e00248-17. Accessed: Accessed: January 4, 2018: 10.1128/MCB.00248-17 